\title{
Effect of Various Feed Phosphates on Biochemical Indices of Blood and Mineral Composition of Bones in Finishing Pigs
}

\author{
Zbigniew Dobrzański ${ }^{1}$, Krystyna Pogoda-Sewerniak $^{1}$, Szymon Dragan $^{2}$, \\ Daniel Korniewicz ${ }^{3}$, Krystyna Hoffmann ${ }^{4}$, Adolf Korniewicz ${ }^{1}$
}

\footnotetext{
${ }^{1}$ Faculty of Biology and Animal Science, Wroclaw University of Environmental and Life Sciences, Poland

${ }^{2}$ Faculty of Medicine, Wroclaw Medical University, Poland

${ }^{3}$ LNB POLAND Ltd, Kiszkowo, Poland

${ }^{4}$ Faculty of Chemistry, Wroclaw University of Technology, Poland
}

Received October 6, 2009

Accepted March 8, 2010

\begin{abstract}
The aim of this study was to evaluate the effect of three different chemical feed phosphates on the blood biochemical indicators and the content of main minerals of bones in finishing pigs.

Over a period of 85 days of fattening, monocalcium (MCP, Finnish product), dicalcium (DCP, Polish product) and calcium-sodium (CSP, Russian product) phosphates were used in fattener feeding. The feeding was based on standard mixtures of starter, grower and finisher type. Dicalcium phosphate was produced according to the new, pro-ecological technology based on phosphoric acid. The content of $\mathrm{Ca}, \mathrm{Na}, \mathrm{P}$, solubility of $\mathrm{P}$ in citric acid, and the concentration of undesirable substances $(\mathrm{As}, \mathrm{Cd}, \mathrm{F}, \mathrm{Hg}$ and $\mathrm{Pb}$ ) were determined in feed phosphates.

At the end of the fattening period, blood was collected from 36 finishing pigs (12 from each group) and the following biochemical indicators were determined in the serum: enzymatic activity of aspartate aminotransferase (AST), alanine aminotransferase (ALT), $\gamma$-glutamyltransferase (GGT), creatine kinase (CK), lactic dehydrogenase (LDH), lactic acid (LA); the concentration of total protein, albumins, glucose, urea, creatinine, content of triglycerides, cholesterol and its high density lipoproteins (HDL) and low density lipoproteins (LDL) fractions, and mineral components concentration ( $\mathrm{Ca}, \mathrm{Cl}, \mathrm{Cu}, \mathrm{Fe}, \mathrm{K}, \mathrm{Mg}, \mathrm{Na}, \mathrm{P}, \mathrm{Zn})$. Basic macroelement content (Ca, Mg, P) was determined in the thigh bones from 30 pigs ( 10 from each group). Significant differences $(p<0.05)$ between groups were observed only in some biochemical indicators, i.e. CK, LDH and LA. The highest content of $\mathrm{Ca}, \mathrm{Mg}$ and $\mathrm{P}$ was found in the bones of pigs fed mixtures supplemented with DCP which indicates improved bioavailability of main macroelements from that phosphate.
\end{abstract}

Feed supplements, fatteners, blood serum, bone composition

Cereal grain, i.e. the main source of phosphorus, is the basic fodder in pig feeding. In cereal grain, phosphorus is present in the form of sparingly available phytates. The introduction of formulation containing an exogenous microbiological phytase to feeding mixtures is a common way of improving phosphorus availability from phytic compounds (Krasucki and Grela 1997; Radcliffe et al. 1999; Steiner et al. 2006). Such procedure may considerably reduce the amount of phosphorus expelled in faeces which is important in terms of environmental protection.

However, the amount of phosphorus available in feed of plant origin, even with the addition of microbiological phytase does not fulfill the demands of intensively growing pigs, and supplementation of the feeding dose with additional $30 \%-50 \%$ mineral phosphorus is necessary (Fandrejewski 1997).

Mono-, di-, and tricalcium, calcium-sodium, sodium-calcium-magnesium and ammonium phosphates are available on the fodder market. The production of dicalcium phosphate (DCP) using a new pro-ecological method has been recently introduced in Poland (Hoffmann et al. 2008). 
The apparent digestibility of phosphorus in these phosphates is often extremely variable, from 51 to $90 \%$, and depends mainly on the technology of production used and the purity of the phosphoric acid employed (Eckhout and Paepe 1997; Poulsen 2007; Gołębiowska et al. 2008).

The aim of the present study was to evaluate the effect of three different feed phosphates including DCP produced using the new method, on the blood biochemical indicators and the content of the main minerals in bones of finishing pigs.

\section{Materials and Methods}

Animals and feeding

Experimental fattening was conducted at the Experimental Animal Feeding Plant in Gorzyń that belongs to the Poznan University of Life Sciences, Poland. The study was conducted on 60 piglets (originating from Large Polish White $\times$ Polish Landrace crossbred sows and Hampshire $\times$ Pietrain crossbred boars) of an average initial body mass of $20 \mathrm{~kg}$. The animals were divided into 3 groups of 20 individuals each, according to the rule of analogues. The fattening lasted 85 days, i.e. until the body mass reached about $110 \mathrm{~kg}$.

The division of piglets into 3 feeding groups followed from the contribution of phosphates analysed in mixtures used during the experimental fattening: group 1 (control) - mixtures with monocalcium phosphate (MCP); group 2 - mixtures with dicalcium phosphate (DCP); group 3 - mixtures with calcium-sodium phosphate (CSP).

Table 1. Nutritional values of "starter", "grower" and "finisher" mixtures

\begin{tabular}{|l|c|c|c|c|}
\hline \multirow{2}{*}{ Feed materials } & \multirow{2}{*}{ Units } & \multicolumn{3}{|c|}{ Mixture } \\
\cline { 3 - 5 } & & Starter & Grower & Finisher \\
\hline In 1 kg of a mixture: & & & & \\
\hline Net energy & Kcal & 2340 & 2280 & 2281 \\
\hline Metabolic energy & $\mathrm{MJ}$ & 13.60 & 13.25 & 13.25 \\
\hline Dry matter & $\%$ & 87.3 & 87.3 & 87.3 \\
\hline Total protein & $\%$ & 17.4 & 15.7 & 14.5 \\
\hline Lysine & $\%$ & 1.17 & 0.93 & 0.85 \\
\hline Methionine & $\%$ & 0.39 & 0.28 & 0.26 \\
\hline Methionie+cystine & $\%$ & 0.71 & 0.60 & 0.55 \\
\hline Threonine & $\%$ & 0.75 & 0.59 & 0.54 \\
\hline Tryptophan & $\%$ & 0.23 & 0.20 & 0.16 \\
\hline Isoleucine & $\%$ & 0.66 & 0.59 & 0.51 \\
\hline Total calcium & $\%$ & 0.73 & 0.68 & 0.60 \\
\hline Total phosphorus & $\%$ & 0.55 & 0.50 & 0.43 \\
\hline Mineral phosphorus*) & $\%$ & 0.16 & 0.15 & 0.13 \\
\hline Digestible phosphorus & $\%$ & 0.34 & 0.30 & 0.25 \\
\hline Bacterial phytase & $\mathrm{FTU}$ & 500 & 510 & 425 \\
\hline Total sodium & $\%$ & 0.20 & 0.20 & 0.14 \\
\hline Iron & $\mathrm{mg}$ & 198 & 183 & 172 \\
\hline Manganese & $\mathrm{mg}$ & 91 & 92 & 73 \\
\hline Copper & $\mathrm{mg}$ & 167 & 25 & 21 \\
\hline Zinc & $\mathrm{mg}$ & 157 & 148 & 126 \\
\hline Iodine & $\mathrm{mg}$ & 1.66 & 1.49 & 1.26 \\
\hline Cobalt & $\mathrm{mg}$ & 0.88 & 0.81 & 0.68 \\
\hline Selenium & $\mathrm{mg}$ & 0.49 & 0.49 & 0.41 \\
\hline
\end{tabular}

*) Mineral phosphorus in equal amount derived from monocalcium (Group I, MCP), dicalcium (Group II, DCP) or calcium-sodium phosphate (Group III, CSP)

$\mathrm{F}, \mathrm{Hg}$ and $\mathrm{Pb}$. The analyses were conducted in a specialist chemical laboratory at the Institute of Inorganic Technology and Mineral Fertilizers in Wroclaw University of Technology using mandatory chemical methods (AOAC 1990).
The contribution of particular feed phosphates resulted from the optimisation of $\mathrm{P}$ content in the mixtures. It was assumed that mineral phosphorus makes up $30 \%$ of the demand for total phosphorus. The contribution of phosphorus in the three mixtures used was as follows: MCP $0.57-0.73 \%$, DCP $0.70-0.89 \%$, and CSP $0.72-0.92 \%$. The nutritional value of starter, grower and finisher mixtures, with mineral components, is presented in Table 1.

\section{Feed phosphates}

Three kinds of phosphates were used in the experiment: monocalcium (MCP, Finnish product), calcium-sodium (CSP, Russian product) and dicalcium (DCP, Polish product). Dicalcium phosphorus was produced from calcium oxide and calcium carbonate, using concentrated phosphoric acid as the phosphorus source. The product obtained in a direct chemical reaction between phosphoric acid and calcium was a phosphoric acid salt with the following chemical formula: $\mathrm{CaHPO} \times 2 \mathrm{H}_{2} \mathrm{O}$. The technology applied was non-scrap and non-sewage autothermal technology using the heat of the reaction to dry the product. Because of the lack of direct drying with gases, the final product thus obtained did not contain any harmful organic substances (Hoffmann and Hoffmann 2009).

Within the chemical assessment of phosphates, the following were determined: the content of $\mathrm{Ca}$, total $\mathrm{P}, \mathrm{P}$ soluble in $2 \%$ citric acid, and the content of undesirable substances such as As, Cd, 
Blood analyses

Blood for laboratory analysis was collected once from 36 pigs (12 from each group) at the end of the fattening period, i.e. day 85 of life, with a body mass of about $110 \mathrm{~kg}$. The blood was collected in the morning, before feeding, from the zygomatic vein, into test tubes containing agents activating the coagulation process (Sigma, Poland). The blood samples were delivered within $2 \mathrm{~h}$ from collection to the biochemical laboratory of the Department of Environment Hygiene and Animal Welfare of Wroclaw University of Environmental and Life Sciences, where serum was separated and the following biochemical indicators were determined: enzymatic activity of aspartate aminotransferase (AST), alanine aminotransferase (ALT), $\gamma$-glutamyltransferase (GGT), creatine kinase (CK), concentration of total protein, albumin, glucose, urea, creatinine, triglycerides, cholesterol and its HDL and LDL fractions, and the concentration of mineral components - $\mathrm{Ca}, \mathrm{Cl}, \mathrm{Cu}, \mathrm{Fe}, \mathrm{K}, \mathrm{Mg}, \mathrm{Na}, \mathrm{P}, \mathrm{Zn}$.

All analyses were done using a Pentra 400 biochemical analyser manufactured by Horiba ABX (Japan), with reagents from the same company. An exception was the determination of $\gamma$-glutamyltransferase concentration which was carried out using reagents produced by Alpha Diagnostics (Poland), and zinc and copper concentration analysis were carried out with Randox (UK) reagents. The concentrations of sodium, chlorides and potassium were conducted via the ionoselective method using the ionoselective attachment integrated with a Horiba ABX Pentra 400 analyser.

Activity of AST, ALT, CK and $\gamma$-glutamyltransferase was determined at a temperature of $37{ }^{\circ} \mathrm{C}$, using the kinetic method according to IFCC (International Federation of Clinical Chemistry) recommendations.

The concentration of total protein, albumin, glucose, creatinine, triglycerides, cholesterol and its fractions was determined by colorimetric tests. In the case of total protein it was a burette reaction, while in the case of albumin concentration, the method using bromocresol green was used. Glucose concentration was determined using an enzymatic method with oxidase reaction. Urea concentration was assessed using a UV enzymatic test, with the contribution of urease and glutamate dehydrogenase, while creatinine was analysed using a modified kinetic method.

Lactic acid (LA) concentration was determined using the enzymatic colorimetric method applying the Trinder's end-point method, where the lactate is an intermediate product of glucose combustion. Lactic oxidase causes the release of hydrogen peroxide that reacts with the two compounds creating a coloured complex in the presence of peroxidase. The colour intensity is proportional to lactate concentration in the sample.

Lactic dehydrogenase (LDH) content was determined using the enzymatic kinetic method optimized in accordance with recommendations of the German Society of Clinical Chemistry (DGKC). LDH activity was determined in a reaction of pyruvate with hydrogen ions and $\mathrm{NADH}$ where lactate and $\mathrm{NAD}^{+}$dinucleotide were formed with the contribution of LDH.

Globulin concentration was determined according to the following formula: globulins $[\mathrm{g} / \mathrm{l}]=$ total protein $[\mathrm{g} / \mathrm{l}]$ - albumins [g/l]. Cholesterol and triglyceride concentration was determined using the enzymatic colorimetric method. HDL fraction was assessed using cholesterol oxidase, and LDL fraction by enzymatic reaction in the presence of a coupling agent.

The content of inorganic phosphorus was determined using the UV-VIS method with the application of phosphomolybdate. Calcium was determined using the photometric method with the application of ortocresolphthalein complexone. Magnesium was determined using the photometric method with xylitol blue. The iron content was determined using the photometric test with pherene; zinc and copper by colorimetric tests.

The concentration of sodium, chlorides and potassium was determined using biochemical analyser Pentra 400 of Horiba ABX Company with ISE module, where the three ionoselective electrodes were used (for $\mathrm{Cl}, \mathrm{K}$ and $\mathrm{Na}$, respectively) and one reference electrode as well.

Chemical composition of bones

The determination of basic macroelement $(\mathrm{Ca}, \mathrm{P}, \mathrm{Mg})$ content in the thigh bones of pigs was conducted at the Food and Environment Analysis Laboratory of the Meat and Fat Research Institute in Warsaw (Poland). Thirty thigh bones from the right half-carcass (10 from each group) were subjected to analysis. Ring shaped samples of a thickness of $3 \mathrm{~mm}$ were collected from each bone. They were cut with a saw from the narrowest part of the thigh bone. Soft parts were removed mechanically using a knife and hot water, and then air-dried. Double weighted amounts of a mass of $0.5-0.6 \mathrm{~g}$ each were prepared. In order to determine the content of $\mathrm{Mg}, \mathrm{P}$ and $\mathrm{Ca}$, the following dilutions were made: $\times 50 ; \times 500 ; \times 1000$. Samples subjected to analysis were mineralized using concentrated nitric acid in a microwave furnace (Milestone of 1200 Mega type). Metals were determined by inductively coupled plasma atomic emission spectroscopy (JY- 138-ULTRACE, Jobin Yvon, France).

Statistical analysis

The results of the study were statistically processed. Mean values and standard deviations were calculated using one-factor analysis of variance, and significance of differences between groups was determined by Duncan's test using Statgraphics v. 5.0 software.

\section{Results and Discussion}

The basic nutrient contents found in $1 \mathrm{~kg}$ of starter, grower and finisher mixtures used in pigs fattening are presented in Table 1 . The content of metabolic energy of amino acid 
Table 2. The results of the chemical analysis of feed phosphates (in $1 \mathrm{~kg}$ of DM)

\begin{tabular}{|c|c|c|c|}
\hline Specification & Monocalcium phosphate & Dicalcium phosphate & Calcium-sodium phosphate \\
\hline Chemical formula & $\begin{array}{c}\mathrm{MCP}) \\
\mathrm{Ca}\left(\mathrm{H}_{2} \mathrm{PO}_{4}\right)\end{array}$ & $\begin{array}{c}(\mathrm{DCP}) \\
\mathrm{Ca} \mathrm{HPO}_{4} \times 2 \mathrm{H}_{2} \mathrm{O}\end{array}$ & $\begin{array}{c}(\mathrm{CSP}) \\
\mathrm{Na}_{2} \mathrm{Ca}_{5}\left(\mathrm{PO}_{4}\right)\end{array}$ \\
\hline $\begin{array}{l}\text { Content of total phosphorus } \\
\text { (P) }(\mathrm{g})\end{array}$ & 227 & 185 & 180 \\
\hline $\begin{array}{l}\text { Solubility of phosphorus in } 2 \% \\
\text { citric acid (\%) }\end{array}$ & 99 & 98 & 98 \\
\hline Content of calcium $(\mathrm{Ca})(\mathrm{g})$ & 177 & 250 & 310 \\
\hline Content of sodium $(\mathrm{Na})(\mathrm{g})$ & - & - & 49 \\
\hline \multicolumn{4}{|l|}{ Undesirable substances: } \\
\hline Fluorine (F) $\mathrm{mg}$ & 450 & 350 & 800 \\
\hline Lead $(\mathrm{Pb}) \mathrm{mg}$ & 5.2 & 1.4 & 4.8 \\
\hline Cadmium (Cd) mg & 5.0 & 2.3 & 0.5 \\
\hline Arsenic (As) mg & 8.1 & 0.7 & 2.4 \\
\hline Mercury (Hg) mg & 0.02 & 0.008 & 0.02 \\
\hline
\end{tabular}

protein and mineral components of these mixtures correspond to recommendations included in the standards for pig feeding (Standards ofPigs Feeding 1993).

The results of the chemical analysis of the phosphates used are presented in Table 2 and prove that the phosphorus content was the highest in $\mathrm{MCP}(227 \mathrm{~g} / \mathrm{kg})$, and calcium content was the highest in CSP $(310 \mathrm{~g} / \mathrm{kg})$. The solubility of phosphorus in $2 \%$ citric acid was very high (98-99\%). Phosphates also contained fluorine and toxic metals ( $\mathrm{As}, \mathrm{Cd}, \mathrm{Hg}, \mathrm{Pb}$ ) but in amounts acceptable for feed within the EU. The values obtained are comparable or lower from the values given by another authors (Wzorek 2006; Poulsen 2007).

Table 3 presents the results concerning the analysis of biochemical indicators of pigs' blood serum. The concentrations of total protein (64.0-65.6 g/l), albumin (39.4-41.8 g/l) and globulin (23.8-24.9 g/l) were similar in all groups and corresponded to reference values (Winnicka 2008). No significant differences were noted in glucose concentration which ranged from $5.10 \mathrm{mmol} / \mathrm{l}$ in group 3 to $5.23 \mathrm{mmol} / \mathrm{l}$ in group 2 . Mean concentration values of lactic acid which is the final product of oxygen-free glucose combustion differed significantly between $4.49 \mu \mathrm{mol} / 1$ in group 1 and $4.97 \mu \mathrm{mol} / 1$ in group $3(p<0.05)$.

The activity of ALT in blood serum was different, ranging from 0.553 to $0.638 \mu \mathrm{kat} / \mathrm{l}$, however, the differences were not significant. The observed activity of AST was similar in groups 2 and 3; a slight increase of its activity was observed in group 1, i.e. $1.053 \mu \mathrm{kat} / \mathrm{l}$, a value close to the upper limit of reference values for this indicator in pigs (Winnicka 2008).

The activity of $\gamma$-glutamyltransferase in the serum of pigs from all groups was similar $(0.548-0.578 \mu \mathrm{kat} / \mathrm{l})$, and exceeded reference values. Analysing the activity of lactic dehydrogenase, significant differences $(p<0.05)$ were found between groups 1 and 3 . In the group with MCP addition, the activity of LDH was the highest $-15.08 \mu \mathrm{kat} / \mathrm{l}$ on average.

Differences were observed between groups 2 and 3 in the activity of creatine kinase, a key enzyme in the bioenergetic processes of cells with an important role in adenosine triphosphate (ATP) homeostasis. The CK value in the latest group was the highest, i.e. $28.83 \mu \mathrm{kat} / 1$ on average.

Average concentrations of urea and ceratinine, i.e. indicators reflecting kidney function, were similar in all the groups. A slightly higher urea concentration compared to other groups was observed in group $1(5.71 \mathrm{mmol} / \mathrm{l})$; similar concentrations of creatinine were found in groups 1 and 3, and the lowest one in group $2(114.1 \mu \mathrm{mol} / \mathrm{l})$. Values for GGT, LDH, 
Table 3. Biochemical indices of blood serum of fatteners

\begin{tabular}{|l|c|c|c|}
\hline \multirow{2}{*}{ Specification } & \multicolumn{3}{|c|}{ Groups - phosphate } \\
\cline { 2 - 4 } & $\begin{array}{c}\text { I } \\
\text { Monocalcium }\end{array}$ & $\begin{array}{c}\text { II } \\
\text { Dicalcium }\end{array}$ & $\begin{array}{c}\text { III } \\
\text { Calcium-sodium }\end{array}$ \\
\hline Total protein $(\mathrm{g} / \mathrm{l})$ & $65.6 \pm 6.5$ & $64.0 \pm 4.7$ & $65.5 \pm 6.7$ \\
\hline Albumins $(\mathrm{g} / \mathrm{l})$ & $41.8 \pm 3.8$ & $39.4 \pm 4.9$ & $41.7 \pm 1.7$ \\
\hline Globulins $(\mathrm{g} / \mathrm{l})$ & $23.8 \pm 6.1$ & $24.6 \pm 4.2$ & $23.9 \pm 7.6$ \\
\hline Glucose $(\mathrm{mmol} / \mathrm{l})$ & $5.13 \pm 0.86$ & $5.23 \pm 0.71$ & $5.10 \pm 0.61$ \\
\hline LA $(\mu \mathrm{mol} / \mathrm{l})$ & $4.49^{\mathrm{a}} \pm 2.00$ & $2.40 \pm 0.49$ & $4.97^{\mathrm{b}} \pm 2.23$ \\
\hline ALT $(\mu \mathrm{kat} / \mathrm{l})$ & $0.553 \pm 0.199$ & $0.638 \pm 0.181$ & $0.608 \pm 0.209$ \\
\hline AST $(\mu \mathrm{kat} / \mathrm{l})$ & $1.053 \pm 0.177$ & $0.984 \pm 0.192$ & $0.982 \pm 0.268$ \\
\hline GGT $(\mu \mathrm{kat} / \mathrm{l})$ & $0.578 \pm 0.147$ & $0.572 \pm 0.112$ & $0.548 \pm 0.131$ \\
\hline LDH $(\mu \mathrm{kat} / \mathrm{l})$ & $15.08^{\mathrm{a}} \pm 2.57$ & $14.78 \pm 2.86$ & $13.90^{\mathrm{b}} \pm 2.64$ \\
\hline CK $(\mu \mathrm{kat} / \mathrm{l})$ & $24.75 \pm 20.86$ & $28.83 \pm 31.87$ & $20.46 \pm 15.40$ \\
\hline Urea $(\mathrm{mmol} / \mathrm{l})$ & $5.71 \pm 0.75$ & $5.22 \pm 0.79$ & $5.28 \pm 0.68$ \\
\hline Creatinine $(\mu \mathrm{mol} / \mathrm{l})$ & $119.6 \pm 13.0$ & $114.1 \pm 13.1$ & $119.9 \pm 8.6$ \\
\hline Total cholesterol $(\mathrm{mmol} / \mathrm{l})$ & $2.40 \pm 0.29$ & $2.40 \pm 0.49$ & $2.30 \pm 0.16$ \\
\hline HDL $(\mathrm{mmol} / \mathrm{l})$ & $1.12 \pm 0.18$ & $1.08 \pm 0.26$ & $1.06 \pm 0.11$ \\
\hline LDL $(\mathrm{mmol} / \mathrm{l})$ & $1.05 \pm 0.14$ & $1.08 \pm 0.24$ & $1.03 \pm 0.14$ \\
\hline Triglycerides TG $(\mathrm{mmol} / \mathrm{l})$ & $0.22 \pm 0.06$ & $0.23 \pm 0.08$ & $0.25 \pm 0.06$ \\
\hline
\end{tabular}

Superscripts a, b: $p<0.05$

$\mathrm{CK}$, urea and creatinine concentration were within or slightly exceeded the range of reference values (Winnicka 2008).

Fat balance in fatteners was assessed, determining the content of triglycerides, total cholesterol, and its LDL and HDL fractions. No significant differences between groups were observed for all of these indicators. The average value of total cholesterol was 2.3-2.4 $\mathrm{mmol} / \mathrm{l}$, which exceeded the reference value (Winnicka 2008). Small differences were observed in the HDL fraction (1.06-1.12 mmol/l). The LDL fraction of cholesterol was also similar in all groups $(1.03-1.08 \mathrm{mmol} / \mathrm{l})$. Triglyceride content in the blood serum of examined pigs was very similar, $0.22-0.25 \mathrm{mmol} / \mathrm{l}$, i.e. half the reference range, on average (Winnicka 2008).

The results of a biochemical study are difficult to interpret unequivocally, since metabolic processes are extraordinarily complex and affected by numerous factors. Dietary protein and fats may have some influence on the results (Usydus 2005; Zraly et. al 2006), and also various inorganic and organic feed components may change the values of blood indicators (Korniewicz et al. 2007; Wang et al. 2009).

Average concentrations of mineral components in the blood serum of pigs are presented in Table 4. The results obtained prove that phosphates administered in the pigs' feed did not significantly influence the concentration of analysed macro- and microelements.

The concentration of calcium was within the range of 2.5-2.6 mmol/1, and phosphorus $3.0-3.1 \mathrm{mmol} / 1$. These values were close to the upper limit of reference values given by Winnicka (2008). Magnesium concentration in the blood serum of pigs was the same in

Table 4. The content of mineral components in blood serum of fatteners

\begin{tabular}{|l|c|c|c|}
\hline \multirow{2}{*}{ Specification } & \multicolumn{3}{|c|}{ Group - phosphate } \\
\cline { 2 - 4 } & $\begin{array}{c}\text { I } \\
\text { Monocalcium }\end{array}$ & $\begin{array}{c}\text { II } \\
\text { Dicalcium }\end{array}$ & $\begin{array}{c}\text { III } \\
\text { Calcium-sodium }\end{array}$ \\
\hline Calcium $(\mathrm{Ca}) \mathrm{mmol} / 1$ & $2.6 \pm 0.1$ & $2.5 \pm 0.2$ & $2.6 \pm 0.1$ \\
\hline Phosphorus $(\mathrm{P}) \mathrm{mmol} / 1$ & $3.0 \pm 0.1$ & $3.1 \pm 0.4$ & $3.1 \pm 0.2$ \\
\hline Sodium $(\mathrm{Na}) \mathrm{mmol} / 1$ & $141.7 \pm 1.3$ & $141.4 \pm 1.5$ & $141.6 \pm 1.4$ \\
\hline Chlorine $(\mathrm{Cl}) \mathrm{mmol} / 1$ & $102.0 \pm 2.6$ & $101.6 \pm 2.3$ & $101.1 \pm 1.9$ \\
\hline Potassium $(\mathrm{K}) \mathrm{mmol} / 1$ & $5.1 \pm 0.6$ & $5.1 \pm 0.5$ & $5.1 \pm 0.4$ \\
\hline Magnesium $(\mathrm{Mg}) \mathrm{mmol} / 1$ & $0.9 \pm 0.1$ & $0.9 \pm 0.1$ & $0.9 \pm 0.1$ \\
\hline Iron $(\mathrm{Fe}) \mu \mathrm{mol} / 1$ & $25.8 \pm 5.5$ & $24.4 \pm 5.1$ & $24.3 \pm 5.9$ \\
\hline Zinc $(\mathrm{Zn}) \mu \mathrm{mol} / 1$ & $10.3 \pm 2.6$ & $9.4 \pm 1.2$ & $9.8 \pm 1.5$ \\
\hline Copper $(\mathrm{Cu}) \mu \mathrm{mol} / 1$ & $38.5 \pm 4.7$ & $38.5 \pm 4.3$ & $38.2 \pm 4.4$ \\
\hline
\end{tabular}
all groups $(0.9 \mathrm{mmol} / \mathrm{l})$, and the sodium content was $141.4-141.7 \mathrm{mmol} / \mathrm{l}$. The content of chlorine and potassium was similar in all groups. Also the concentration of iron was similar in all groups (24.3-25.8 $\mu \mathrm{mol} / \mathrm{l})$, similarly as zinc $(9.4-10.3$ $\mu \mathrm{mol} / \mathrm{l})$ and copper (38.2-38.5 $\mu \mathrm{mol} / 1)$. The lack of differences between groups may 
Table 5. The content of mineral components in thigh bones $(\mathrm{g} / \mathrm{kg})$

\begin{tabular}{|l|c|c|c|}
\hline \multirow{2}{*}{ Component } & \multicolumn{3}{|c|}{ Group - phosphate } \\
\cline { 2 - 4 } & $\begin{array}{c}\text { I } \\
\text { Monocalcium }\end{array}$ & $\begin{array}{c}\text { II } \\
\text { Dicalcium }\end{array}$ & $\begin{array}{c}\text { III } \\
\text { Calcium-sodium }\end{array}$ \\
\hline Calcium $(\mathrm{Ca})$ & $250.6^{\mathrm{b}} \pm 7.5$ & $262.1^{\mathrm{a}} \pm 9.1$ & $253.0^{\mathrm{b}} \pm 5.4$ \\
\hline Phosphorus $(\mathrm{P})$ & $118.6^{\mathrm{b}} \pm 3.5$ & $142.2^{\mathrm{a}} \pm 2.4$ & $122.2 \pm 1.9$ \\
\hline Magnesium $(\mathrm{Mg})$ & $3.85^{\mathrm{b}} \pm 0.17$ & $4.24^{\mathrm{a}} \pm 0.24$ & $4.16 \pm 0.14$ \\
\hline
\end{tabular}

Superscripts a, b: $p<0.05$ be explained by similar chemical composition of the phosphates administered; however, in the study conducted by Korniewicz et al. (2010) it was demonstrated that pigs fed mixtures with the addition of a new

dicalcium phosphate retained significantly higher amounts of $\mathrm{Ca}, \mathrm{Cu}, \mathrm{Mg}, \mathrm{Mn}$ and $\mathrm{P}$.

It is known that organic forms of microelements are more easily available. Novotný et al. (2005) applied $\mathrm{Fe}, \mathrm{Cu}, \mathrm{Mn}, \mathrm{Zn}$ and $\mathrm{Se}$ in a traditional or organic form to feed for piglets. They observed a significant effect of the organic form on the increase in concentrations of these microelements: Fe from 14.7 to $18.3, \mathrm{Cu}$ from 17.8 to $22.7, \mathrm{Zn}$ from 8.5 to $9.5, \mathrm{Mn}$ from 0.4 to $0.6 \mu \mathrm{mol} / 1$. Czech and Grela (2006) after administering mineral chelates in feed for fatteners observed a significant increase in the content of $\mathrm{Cu}, \mathrm{Mn}$ and $\mathrm{Zn}$ in blood serum compared to the control group. Also, other authors noted the effect of various forms of iron or zinc on the concentration of some blood indicators in pigs (Svoboda 2004; Rekiel and Więcek 2005).

The results of the chemical analysis of thigh bones concerning $\mathrm{Ca}, \mathrm{P}$ and $\mathrm{Mg}$ content are presented in Table 5. Calcium concentration in group 2 (DCP) was significantly higher $(262.1 \mathrm{~g} / \mathrm{kg})$ compared to groups 1 and 3. DCP used in feed mixtures influenced the increase in the phosphorus content $(124.2 \mathrm{~g} / \mathrm{kg})$, and the difference with respect to group 1 was significant. Magnesium content in the thigh bones of pigs from group 2 was also significantly higher $(4.24 \mathrm{~g} / \mathrm{kg})$ than in pigs from group $1(3.85 \mathrm{~g} / \mathrm{kg})$.

Similar concentrations of mineral components in thigh bones of sows were observed by Gajewczyk (1983). According to that author, calcium constituted 23\%, phosphorus $15 \%$ and magnesium $0.55 \%$ of the dry matter of bone. When analysing the chemical composition of metacarpal, metatarsal and thigh bones of sows, Fuchs et al. (1993) demonstrated that $\mathrm{Ca}, \mathrm{P}$ and $\mathrm{Mg}$ concentrations in the dry matter were the same in spite of administration of various feed phosphates. Slightly different data for the range of $\mathrm{Ca}$ and $\mathrm{P}$ accretion and resorption in pigs of a body mass of $65 \mathrm{~kg}$ are given by Fernandez (1995). The author observed that an accretion relative to bone ash declined with live weight, and conversely, daily accretion increased with live weight due to larger bone mass. Bone resorption of $\mathrm{Ca}$ and $\mathrm{P}$ was strongly and negatively related to mineral intake and accounted nearly exclusively for the increases in dietary intake and intestinal absorption.

Generally, the three different phosphates used in the experiment did not significantly influence the differentiation of biochemical indicators of the blood of pigs (except for CK, $\mathrm{LDH}$ and LA). The highest concentrations of $\mathrm{Ca}, \mathrm{P}$ and $\mathrm{Mg}$ in the thigh bones of pigs in the group given DCP may prove better bioavailability of those building elements in pigs, which is of major importance in fast-growing animals.

\section{Acknowledgements}

The present study was conducted within the framework of research project No. R 0504203 financed by the Polish Ministry of Science and Higher Education.

\section{References}

AOAC 1990: Official Methods of Analysis of the Association of Official Analytical Chemists $15^{\text {th }}$ ed. Arlington, Virginia

Czech A, Grela ER 2006: The influence of mineral chelates addition in mixtures for growing pigs on the growth and blood components. Ann. UMCS Lublin, sect. EE, 16: 111-117 (in Polish) 
Eackhout BY, W Paepe MDE 1997: The digestibility of three calcium phosphates for pigs as measured by difference and by slope-ratio assay. J Anim Physiol Anim Nutr 77: 53-60

Fandrejewski H 1997: The possibilities of the limitation of phosphorus excretion by pigs. Conference: "Feeding methods of the limitation of excretion of nitrogen, phosphorus and other elements by livestock to the environment." Inst Zoot, Kraków, pp. 45-64 (in Polish)

Fernández JA 1995: Calcium and phosphorus metabolism in growing pigs. II. Simultaneous radio-calcium and radio-phosphorus kinetics. Livest Prod Sci 41: 243-254

Fuchs B, Preś J, Wiliczkiewicz A, Schlaicher A, Szyńcowicz E 1993: The influence of phosphates kind on production results. Physiological indices, retention and digestibility of nutrients and mineral components in pigs. Rocz Nauk Zoot Monogr Rozpr 32: 225-234 (in Polish)

Gajewczyk P 1983: An attempt to determine an influence of an acclimatization of wbp and pbz bred sows on an industrial farm on their osseous system and chosen physical and chemical properties of thigh bone. Zesz Nauk AR, Wrocław, Zoot 25: 89-99 (in Polish)

Gołębiowska A, Wilk K, Kwiatek K 2008: Source and role of phosphorus an mixtures used in animals feeding. Pasze Przem 8/9: 14-15 (in Polish)

Hoffmann J, Hoffmann K 2009: The study on the process of feed calcium phosphates manufacturing using a concentrated phosphoric acid. Przem Chem 5: 450-453 (in Polish)

Hoffmann J, Hoffmann K, Korniewicz D, Dobrzański Z, Korniewicz A 2008: Physico-chemical assessment of different kinds of feed phosphates. Chem Agric 9: 25-30

Korniewicz D, Dobrzański Z, Chojnacka K, Korniewicz A, Kołacz R 2007: Effect of dietary yeast enriched with $\mathrm{Cu}, \mathrm{Fe}$ and $\mathrm{Mn}$ on digestibility of main nutrients and absorptions of minerals by growing pigs. Am J Agric Biol Sci 2: $267-275$

Korniewicz D, Hoffmann J, Korniewicz A, Dobrzański Z 2010: An influence of various feed phosphates on a digestibility of nutrients, balance and apparent absorption of mineral components in fatteners. J Anim Feed Sci (in press)

Krasucki W, Grela E 1997: An influence of phytase and formic acid addition in mixtures for sows on digestibility of nutrients in pigs. Feed additives in animals feeding. Proc XXVI Conf KNZ PAN. Olsztyn 15-16 October, 63-65 (in Polish)

Novotny J, Seidel H, Kovac G, Babcek R 2005: Bioavailability of trace elements proteinates in pigs. Medycyna Wet 61: 38-41

Poulsen HD 2007: Phosphorus availability in feed phosphates determined by regression. Livestock Sci 109: 247-250

Radcliffe JS, Pleasant RS, Kornegay ET 1999: Estimating equivalency values of microbial phytase for amino acids in growing and finishing pigs fitted with steered ileo-cecal valve cannulas. J Anim Sci 84: 1119-1129

Rekiel A, Więcek J 2005: Biochemical indices of blood serum of fatteners fed with a mixture with zinc oxide addition. Rocz Nauk PTZ 1: 115-121 (in Polish)

Standards of Pigs Feeding, Nutritional value of fodders. 1993. Wyd. Instytutu Fizjologii i Żywienia Zwierząt, PAN Jabłonna-Warszawa (in Polish)

Steiner T, Mosenthin R, Fundis A, Jakob S 2006: Influence of feeding level on apparent total tract digestibility of phosphorus diets supplemented with microbial or wheat phytase. Livestock Sci 102: 1-10

Svoboda M, Bouda J, Drábek J, Doubek J 2004: Effect of per os iron lactate supplement on development of haematological profile of piglets in the early postnatal period. Acta Vet Brno 73: 431-436

Usydus Z 2005: The study of manufacturing and quality of feed fish oil and its application in a form of fishmineral concentrate in monogastric animals feeding. Zesz. Nauk. AR we Wrocławiu, Rozpr 513: 1-103 (in Polish)

Wang JP, Yoo JS, Kim HJ, Lee JH, Kim IH 2009: Nutrient digestibility, blood profiles and fecal microbiota are influenced by chitooligosaccharide supplementation of growing pigs. Livest Sci 123: 298-303

Winnicka A 2008: Reference values of basic laboratory analysis in veterinary medicine. Ed. SGGW, Warszawa (in Polish)

Wzorek Z 2006. The alternative phosphoric raw materials. Przem Chem 85: 880-882 (in Polish)

Zralý Z, Písaříková B, Trčková M, Herzig I, Jůzl M, Simeonovová J 2006: Effect of lupine and amaranth on growth efficiency, health, and carcass characteristics and meat quality of market pigs. Acta Vet Brno 75: 363-372 
